\title{
The Challenges of Villages in the Era Of the Industrial Revolution 4.0: A Study on Policy Implementation of "Smart Kampung" in Jajag Village of Banyuwangi Regency
}

\author{
Hervina Dwi Wulandari', Anisya Gita Prasehana ${ }^{2}$, Rapla Diarola Aparta ${ }^{3}$ \\ ${ }^{1,2,3}$ Master of Public Policy, Faculty of Social and Political Sciences, Airlangga University, \\ Surabaya \\ 1.hervinadwiw@gmail.com,
}

\begin{abstract}
Information Technology is one of the many developments that are currently developing, especially in Indonesia. Technology seems to be the basic foundation of community needs in the face of the development of the times demanded that must follow the development of 4.0. At this time, technology covers not only major cities but also covers remote areas. Seeing the development of increasingly advanced technology, in Indonesia, precisely in Banyuwangi Regency, it is implemented a program called Smart Kampung. By adopting the Smart City program concept, Banyuwangi Regency implements the Smart Kampung program, which is part of the community development concept, which is clever/smart/wise in overcoming various human resource problems. This study is a descriptive study with a qualitative approach. The data collection techniques in this study used interview, observation, and documentation techniques with the informants and the parties involved. The Smart Kampung program aims to build more advanced human resources in the village. The Banyuwangi Regency Government wants to make the villages in Banyuwangi become an independent village supported by information technology of smart kampung program.
\end{abstract}

Keywords: Implementation, Smart Kampung, Technology

\section{INTRODUCTION}

Seeing the increasingly advanced development of eras makes the phenomenon of the industrial era 4.0 has now entered Indonesia where in that era, Indonesia is headed towards information for the community which is marked by an increase in connectivity, the existence of interaction interactions, the boundaries between humans, machines, and resources that support the others. Industry 4.0 era can be defined as a digital-based era in which in this era, human life is supported by the advancement of sophisticated information technology. Information technology seems to be a basic human need at this time, especially the development of the era demands that we must follow the development of 4.0. [1] The development of information technology in the industry 4.0 era has entered the world of government, where governance is demanded to be able to innovate, be more adaptive, and transparent. The industrial revolution 4.0 requires the government to use the digitization system in all its activities, including in the aspect of public services [2]. 
The government implements various kinds of innovations to create good governance from the central government to the regional government supported by information technology so that the services provided by the government can run effectively and efficiently. The rapid progress of information technology today has made the government make innovations to be able to answer the various challenges that existed in the revolution 4.0 era. The sophisticated information technology does not only exist in the industrial field but is also used in the construction of a city, such as a smart city [3]. The smart city is a city innovation that carries the concept of a smart city by utilizing information and communication technology with the possessed resources to improve the quality of human life to be more effective and efficient.

The implementation of smart city has been done by many major cities in Indonesia, such as Jakarta, Bandung, Makassar, and Surabaya. Different to some major cities in Indonesia that have implemented smart city concept, one area that is currently being intensively making various innovations is Banyuwangi Regency. By adopting the concept of a smart city, Banyuwangi Regency built a program called Smart Kampung. Smart Kampung itself is a program of Banyuwangi Regency government that aims for village development so that public services can be closer to the community up to the village level, in which each village has been integrated with information technology. The Smart Kampung program was launched as a pilot project on May 31, 2016, and Jajag Village was as one of the models of Smart Kampung. Referring to the Regent Regulation (PerBup) Number 18 of 2016 concerning the Integration of Village/Small Town Based Work Programs through smart kampung, it can be seen in article 1 that the smart kampung program is part of a community-based development concept which is clever/smart/wise in terms of to overcome various human resource problems [4]. Thus, it can be said that with this smart kampung program, the existing human resources in the village can be built so that the development of human resources is more advanced.

The Banyuwangi Regency Government implements a smart kampung program not merely to advance human resources. Besides, the Banyuwangi Regency Government wants to make villages more independent. The independent concept here can be interpreted that all the community, especially in the village, who have difficulty in obtaining public services, who have difficulty in accessing the Internet to access their needs, such as the need to register for E-KTP (Electronic ID Card), KK (Family Card), and other documents. The existence of smart kampung makes the community who live far away in the village more easily manage data and documents needed because basically, managing data and documents directly to the office will require quite a long time. In other words, it is very not effective when managing data and documents on the spot (directly in the office). However, in reality, this smart kampung program did not run smoothly [5]. There are still some obstacles in the field that are experienced in several aspects. The main obstacle is the lack of mastery of Information Technology which is still a barrier until now. Besides, other obstacles are regarding human resources, in which the human resources in villages that are still not yet qualified. The qualified concept here means there is still a lack of understanding of the advance of the village expected by the Banyuwangi Regency Government through the implementation of the smart kampung program.

Based on the explanation above, a study on the Implementation of Smart Kampung Program in the Revolution 4.0 Era is interesting to analyze because basically, the Smart Kampung program adopts the concept of smart city that has been applied in several major cities in Indonesia and Banyuwangi adopts it as smart kampung program that are applied to villages in Banyuwangi. In this study, the researchers used the Model Policy Implementation theory by George C. Edward III, which in the public policy implementation model, there is the term of Direct and Indirect Impact on Implementation. In the approach theorized by Edward III, there 
are four variables that can determine the successful implementation of a policy. Those four variables are (i) Communication; (ii) Resource; (iii) Disposition; and (iv) Bureaucratic structure.

\section{RESEARCH METHOD}

This study discusses the Implementation of the Smart Kampung Program in the Revolution 4.0 Era conducted by the Banyuwangi Regency Government. In this study, the researchers used qualitative research methods with the type of descriptive approach. According to [6], "Qualitative research is an assessment procedure that produces descriptive data in the form of written or spoken words from people and observable behavior". In this study, the researchers came directly to the field to conduct research using data collection techniques of interview, observation, and documentation study.

Interviews are conversational activities to look for material (information, opinions) through verbal questions and answers with anyone who is required. The conversation is carried out by two parties, consisting of the interviewer who asks the question and the informant or interviewee who provides answers to the questions. The interviews are conducted to reveal the background, motives that exist regarding the problem of observation [7]. The researchers conducted interviews using interview guidelines that contain a series of topic questions that will be asked to informants or interviewees related to the research problem and the results of the interviews are used as data collection material.

The second data collection technique is the observation that can be defined as a complex process, which is structured by various biological and psychological processes. Two of the most important ones are the processes of observation and memory [8]. In this case, in conducting data collection, the researcher states honestly to the informant that the researcher is conducting research. Thus, the informant knows and understands from the beginning to the end of the researcher's activities. The tool used is a field note to record the data needed. The last is the documentation study. According to Arrikunto documentation is "an effort to search for information in the form of notes, transcripts, books, newspapers, magazines, inscriptions, minutes of meetings, leggers, agendas, etc [9]."

Research subjects are materials or targets in a study conducted. Arikunto revealed that the research subject is "objects, things, people, or places of data for the research variables attached and questioned [9]." In this study, the research subject is the Jajag Village Office. While the informants who provide the information and data needed related to the smart kampung program are the Head of the Jajag Village and the IT Staff of the Jajag Village Office.

\section{RESULTS AND DISCUSSION}

This An organization basically always emphasizes the results of achievement of its programs. In this case, referring to the implementation of the smart kampung program planned by the Banyuwangi Regency Government, it aims to improve community competitiveness and the quality of its resources. According to George C. Edward III, there are four variables that must be done in policy implementation so that an implementation can be categorized as successful: (1) Communication, (2) Resources, (3) Disposition, (4) Bureaucratic structure [10]. a. Communication

Based on Edward III's theory, communication is very determining success in achieving the objectives of public policy implementation. Effective implementation occurs when policy/decision-makers already know what they are going to do. Knowledge of what they will 
do can work if every policy/decision is transmitted (communicated). There are three indicators used in measuring the success of this communication variable, which are:

Transmission, in which the communication is appropriately channeled and can produce a good implementation as well so that miscommunication does not occur because of communication that is expected to be distorted in the middle of the process. In the smart kampung program in Banyuwangi Regency, the transmission process is carried out by involving the village party in socializing the program. In addition, the village party also often utilizes Social Media to share information with the community. This effort is quite effective because based on the observation in the field, it shows that almost all community members know and understand about the smart kampung program.

Clarity, in which the communication received by the implementers of policies (Street level bureaucrats) must be clear and not confusing so as not to obstruct the implementation process. A program will be able to run well if the aims and objectives are interpreted the same ranging from the highest level to the lowest executor. So far, what is the goal of the smart kampung in the Jajag Village runs and shows the progress that is in line with what has been planned.

Consistency, in which the order given to carry out an implementation must be applied and run consistently. If it changes, it can cause confusion for implementers in the field. The consistency of the Banyuwangi Regency Government in communicating the smart kampung program is very consistent, which is to create an independent village and superior human resources

An implementation can be categorized as successful if individuals or communities can accept and understand the measurements, values, and objectives contained in the policy itself. In communicating a policy, policy makers must have good knowledge and understanding of what they are conveying so that every policy or decision delivery can be conveyed correctly, accurately and consistently. The smart kampung program planned by the Banyuwangi Regency Government is under the Regent Regulation Number 18 of 2016 concerning the Integration of Village/Small Town Based Work Programs through smart kampung. On the basis of the regent regulation, the implementation of the smart kampung, especially in Jajag Village, is carried out under the leadership of a village head. The village head has the authority and responsibility to implement and deliver the smart kampung program to the community based on the Regent Regulation Number 18 of 2016 concerning the Integration of Village/Small Town Based Work Programs through smart kampung. Besides, the village head has the aim to prosper his community, especially in terms of providing services to the community

\section{Resource}

In the resource variable, George C. Edward III divides it into four categories:

\begin{tabular}{ll} 
Staff & $\begin{array}{l}\text { In the implementation of the Smart Kampung program in Jajag Village, } \\
\text { Banyuwangi Regency, there are expert staffs involved. They consist of an } \\
\text { operator and the head of village auxiliary affairs. The staffs involved are } \\
\text { people who are experts in their fields, so their role is also very helpful in } \\
\text { the implementation of the smart kampung. }\end{array}$ \\
\hline Information & $\begin{array}{l}\text { Information related to the Smart Kampung program in Jajag Village can } \\
\text { be categorized as conveyed well to the community. Although there are still } \\
\text { some that have not been conveyed properly, it is due to differences in levels } \\
\text { in the community, such as because the community education factor is } \\
\text { different from one another. }\end{array}$
\end{tabular}




\begin{tabular}{|c|c|}
\hline Authority & $\begin{array}{l}\text { There is an authority run by the Head of Jajag Village in implementing the } \\
\text { Smart Kampung Program. The authority is based on the Regent Regulation } \\
\text { Number } 18 \text { of } 2016 \text { concerning the Integration of Village/Small Town } \\
\text { Based Work Programs through smart kampung. Based on the regulation, } \\
\text { the Village Head has the authority to implement the smart kampung } \\
\text { program in Jajag Village. }\end{array}$ \\
\hline Facility & $\begin{array}{l}\text { Facilities are very supportive in carrying out an implementation. In } \\
\text { addition to staff owned by the office, implementation of the policy must } \\
\text { also be assisted by supporting facilities, both facilities and infrastructure. } \\
\text { In Jajag Village, besides being supported by existing staff, the } \\
\text { implementation of the Smart Kampung program is also supported by the } \\
\text { existence of self-help funds. There is the fund from the Village Fund } \\
\text { Allocation (ADD) in order to procure facilities and infrastructure needed } \\
\text { by the village such as computer equipment, Family Card printing } \\
\text { equipment, Identity Card printing equipment. Thus, all services can be } \\
\text { done only in the village. }\end{array}$ \\
\hline
\end{tabular}

\section{b. Disposition}

According to Edward, disposition or known as 'attitude of the policy implementers' is an important variable in policy implementation. Disposition in the implementation of the smart kampung program is that the smart kampung program policy is the responsibility of the village head. What has been done by the head of division (Kasi) and head of affairs (Kaur) remains under the supervision of the village head who is commanded by the village secretary. This smart kampung program is also a program that is very acceptable to the community, especially the community of Jajag Village because with the smart kampung, the service will be more effective and efficient [11].

\section{c. Bureaucratic structure}

A bureaucratic structure can be defined as a characteristic, norm, or pattern that repeatedly occurs in an executive agent to implement a policy that has a good relationship both potential and real. In the smart kampung program in Jajag Village, the executive has been divided in each region (perdapil) and they are quite active in the implementation of the smart kampung program. Before the village takes a step in to serve the community, norms have been delivered to the community and coaching is scheduled in accordance with the APBDes. The coaching can be in the form of the importance of the Identity Card (KTP), Family Card (KK) for the community and the importance of the smart kampung program. The relationship between the executive and the village government is very close and there are no problems with programs and guidance explained to the community. The executive always accompanies, supports, and budgets the smart kampung program.

\section{CONCLUSIONS}

It can be seen from the implementation of the smart kampung program to answer the challenges of the revolution 4.0 era which is under the Regent Regulation Number 18 of 2016 concerning the the Integration of Village/Small Town Based Work Programs through smart kampung, that the smart kampung program implemented in Jajag Village has run well, although there are still 
some things that have not been as expected because of several factors that occur. There are limitations of the community who still cannot accept the smart kampung program properly.

\section{REFERENCES}

[1] C.-P. Lim and L.-Y. Tay, Using ICT tools to engage students in higher-order thinking skills. Singapore: Nanyang Technological University and River Valley Primary School., 2006.

[2] J. L. Perry, "Antecedents of public service motivation," in Public Service: Callings, Commitments and Contributions, 2018.

[3] F. Anindra, H. L. H. S. Warnars, and D. M. Min, "Smart City Implementation Modelling in Indonesia with Integration Platform Approach," in Proceedings of 2018 International Conference on Information Management and Technology, ICIMTech 2018, 2018.

[4] P. K. Banyuwangi, Peraturan Bupati Banyuwangi No.18 Tahun 2016 tentang Integrasi Program Kerja Berbasis Desa/Kelurahan Melalui Smart Kampung. 2016.

[5] A. Bhadoria, K. Sahoo, B. Sahoo, A. Choudhury, N. Sufi, and R. Kumar, "Childhood obesity: Causes and consequences," J. Fam. Med. Prim. Care, 2015.

[6] M. Kasirom, "Metodologi Penelitian Kuantitatif-Kualitatif," in Malang: UIN Maliki Press, 2010.

[7] I. M. Wirartha, Metodologi Penelitian Sosial Ekonomi. 2006.

[8] Sugiyono, "Metode Penelitian Pendidikan Pendekatan Kuantitaif, Kualitatif, dan R\&DSugiyono. 2013. 'Metode Penelitian Pendidikan Pendekatan Kuantitaif, Kualitatif, dan R\&D.' Metode Penelitian Pendidikan Pendekatan Kuantitaif, Kualitatif, dan R\&D. https://doi.org/10.1," Metode Penelitian Pendidikan Pendekatan Kuantitaif, Kualitatif, dan R\&D. 2013.

[9] S. Arikunto, "Prosedur Penelitian Suatu Tindakan Praktik," Jakarta: Rineka Cipta, 2006.

[10] M. C. Chang, S. Shaeffer, S. Al-Samarrai, A. B. Ragatz, J. de Ree, and R. Stevenson, Teacher reform in Indonesia: The role of politics and evidence in policy making. Washington D.C.: The World Bank, 2014.

[11] K. Saddhono, "Cultural and Social Change of Foreign Students in Indonesia: The Influence of Javanese Culture in Teaching Indonesian to Speakers of Other Languages (TISOL)," in IOP Conference Series: Earth and Environmental Science, 2018, vol. 126 , no. 1. 